\title{
The Influence of Ecological Knowledge and Product Attributes in Forming Attitude and Intention to Buy Green Product
}

\author{
Budhi Haryanto ${ }^{1}$ \\ ${ }^{1}$ Economic Faculty, SebelasMaret University, Surakarta, Indonesia \\ Correspondence: Budhi Haryanto, Economic Faculty, SebelasMaret University, Surakarta, Indonesia. E-mail: \\ budhiharyanto@yahoo.com or budhiharyantouns@gmail.com
}

\author{
Received: October 7, 2013 Accepted: November 20, 2013 Online Published: March 24, 2014 \\ doi:10.5539/ijms.v6n2p83 URL: http://dx.doi.org/10.5539/ijms.v6n2p83
}

\begin{abstract}
Air-Conditioning of non-Chloro Flour Carbon (AC of non-CFC)) is one of the products categorized as green product. In this context, consumer will consider ecological knowledge as a one of an importance variable in influencing the buying process of this product. Moreover, functional and emotional attribute are next variables as part of product attributes considered importance by consumer in deciding to buy the product. This study investigated the influence of ecological knowledge and product attributes (functional and emotional attributes) on attitude and intention to buy the product. Convenience sampling technique was used to collect 200 consumers who intend to buy AC of non-CFC in Surakarta, Indonesia. Structural equation model was chosen to elaborate the linkage among of variables. The result indicates that attitude toward green product is positively influenced by ecological knowledge. Besides that, functional attribute and emotional benefit were found to influence the intention to buy this product. In this study, the results were not significant, also discussed. Furthermore, the study also revealed the implications both from theoretical and practical aspects, as well as the possibility to do the advance studies.
\end{abstract}

Keywords: green product, ecological knowledge, attitude toward green product, intention to buy green product

\section{Introduction}

Environmentally friendly products are defined as the products that promote quality of life and preservation of natural resources (Treager et al., 1994; Vlosky et al., 1999). In this context marketers have a social responsibility to promote nature conservation and the environment and friendly to the environment and respect the existence of all living beings without exception. This issue is considered important to investigate because on the one hand, the growing phenomenon has led to problems of social responsibility to be aware of related to the fulfillment of the needs to pay attention to aspects of health and wellbeing in the long term (Holbrook \& Moore, 1981; Kalafatis et al., 2000; Hartmann et al., 2005), while on the other hand, the results may provide insights to the marketers in order to create the strategies that should be done to influence the public awareness in willing to buy the environmentally friendly products, especially the Air-Conditioning of non CFC (Aaker \& Shansby, 1982; Blankson \& Kalafatis, 1999; Franzen \& Bouwman, 2001).

Related to the issue of green products, previous studies still show the diversity of decision variables that are used to describe the product purchase decisions (Schlegelmilgh et al., 1996; Kalafatis et al., 1999; Laroche et al., 2001; Narasimhan, 2003; Hartmann et al., 2005). This condition can occur, because each of these studies is oriented to solve the problem, which is adapted to the objects and settings in which the study was conducted. This means that every model is limited in its application. Thus this condition gives an opportunity to this study to design an alternative model, which is incompatible with the object and the background profile of the concerning research. So it is hoped through this way, the resulting model can explain the observed phenomena well.

In this study, the model is constructed to explain the behavioral process of consumers in purchasing the Air-Conditioning of non-CFC in Indonesia. There are five observed variables namely the ecological knowledge, the functional attributes, the emotional benefits, the positive attitude towards environmentally friendly products, and the purchase intentions for the product. 


\section{Theoretical Background and Hypothesis}

Green products become an attractive issue for the studied due to the growing public awareness of the desire to improve the quality of life and environment that can harm health (Schwartz, 1994; Sethuraman \& Cole, 1999). This means that the eco-conscious consumers tend to direct their purchases on environmentally friendly products (Starughan \& Robert, 1999; Hartmann et al., 2005). This study is expected to provide an understanding of the need for caution in formulating policies in marketing field (Kotler, 2000), associated with the efforts that must be done to improve the ecological knowledge, attitudes and purchase intentions towards environmentally friendly products.

\subsection{Study Position}

Associated with the model, the position of this study can be described by Table 1 . Through this tables can be known, that this study did not reveal anything new related to the variable used to build the model. The model is constructed based on the observation variables are identified based on behavioral problems that occur in the area of the object of observation. Here is an explanation of the variables that used to build the model, which was subsequently followed by the formulation of hypotheses.

Table 1. Study position

\begin{tabular}{|c|c|c|c|c|}
\hline Author/year & Independent variable & Dependent variable & Mediating variable & Statistical method \\
\hline $\begin{array}{l}\text { Schlegelmich et al. } \\
\text { (1996) }\end{array}$ & $\begin{array}{l}\text { Environmental knowledge, } \\
\text { environmental attitude, } \\
\text { recycling behavior, political } \\
\text { action }\end{array}$ & Individual purchasing & - & Regression \\
\hline Chan (1999) & $\begin{array}{l}\text { Culture, environmental } \\
\text { knowledge }\end{array}$ & Actual commitment & $\begin{array}{l}\text { Environment affect, } \\
\text { verbal commitment }\end{array}$ & SEM \\
\hline $\begin{array}{l}\text { Kalafatis et al. } \\
\text { (1999) }\end{array}$ & $\begin{array}{l}\text { Outcome belief, referent } \\
\text { belief, control belief }\end{array}$ & $\begin{array}{l}\text { Attitude to behavior, } \\
\text { subjective norms, perceived } \\
\text { control, intention, behavior }\end{array}$ & - & SEM \\
\hline $\begin{array}{l}\text { Laroche et al. } \\
\text { (2001) }\end{array}$ & $\begin{array}{l}\text { Individualism, collectivism, } \\
\text { security, fun/enjoyment, } \\
\text { knowledge }\end{array}$ & $\begin{array}{l}\text { Consumers' attitude, } \\
\text { behavior willingness to pay, } \\
\text { consumers' behavior }\end{array}$ & $\begin{array}{l}\text { Age, gender, income, } \\
\text { education, } \\
\text { employment status, } \\
\text { home ownership } \\
\text { marital status, family } \\
\text { size }\end{array}$ & $\begin{array}{l}\text { Discriminant } \\
\text { analysis }\end{array}$ \\
\hline Narasimhan (2003) & $\begin{array}{l}\text { Knowledge, attitude, } \\
\text { recycling behavior, political } \\
\text { action }\end{array}$ & $\begin{array}{l}\text { General purchasing } \\
\text { behavior, specific } \\
\text { purchasing behavior }\end{array}$ & $\begin{array}{l}\text { Age, sex, education, } \\
\text { social class }\end{array}$ & Regression \\
\hline $\begin{array}{l}\text { Hartmann et al. } \\
(2005)\end{array}$ & $\begin{array}{l}\text { Green brand positioning } \\
\text { functional attribute, green } \\
\text { brand positioning emotional } \\
\text { benefits }\end{array}$ & Brand attitude & - & SEM \\
\hline $\begin{array}{l}\text { Maciag \& Hepting } \\
\text { (2008) }\end{array}$ & $\begin{array}{l}\text { Product selection, attribute } \\
\text { rankings }\end{array}$ & Decision accuracy. & - & SEM \\
\hline The present study & $\begin{array}{l}\text { Ecological knowledge } \\
\text { Functional attributes, } \\
\text { Emotional benefit }\end{array}$ & Behavior intention & Attitude & SEM \\
\hline
\end{tabular}

\subsection{Ecological Knowledge}

Ecological knowledge is defined as an individual's ability to identify and define the symbols and concepts related to ecological environmental problems, which in turn affects the behavior in life. However, individual ecological knowledge of environmentally friendly products, for most consumers have not yet effective that have not made a purchase of environmentally friendly products. Specifically, ecological knowledge is estimated to affect consumer behavioral process of environmentally friendly products, and marketers respond by providing information for decision-making (Laroche et al., 2001; Maciag \& Hepting, 2008). 
In the model, the environmental variable is thought to influence the process of purchasing environmentally friendly products. This can be explained by several studies conducted by Laroche et al. (2001) which explains the different relationships related to environmental issues. The variables that are meant are knowledge, affects, intentions, and behavior of the environment. Of the four variables, the relationship between environmental knowledge and behavior of consumers, yet still showed inconsistent results. This can be explained on a study conducted Chan (1999) which indicates there is an insignificant relationship between environmental knowledge and consumer behavior.

In the model, attitude towards environmentally friendly products is a construct that is designed as a predictor of consumer behavior towards environmentally friendly products. This refers to the theory of planned behavior apply in an environmentally sound product (Fishbein \& Middlestadt, 1995; Kalafatis et al., 1999). Alleged that the behavioral in buying the product, attitude and belief is a function of the outcomes contained in the minds of individuals who subsequently can influence behavioral intentions.

Relation to environmentally friendly products, ecological knowledge allegedly have a positively relation to attitudes toward environmentally friendly products. This opinion refers to the study proposed by Chan (1999) that ecological knowledge as an individual's knowledge of issues related to the environment. Thus, the hypothesis is formulated:

H1: The higher the ecological knowledge of individuals, the higher the positive attitude towards environmentally friendly products.

\subsection{Functional Attributes}

Functional attributes shows the degree of consumer understanding toward the characteristics of product from functional usefulness side in making a purchase environmentally friendly products. Consumers who have purchased environmentally friendly products usually see long term benefits that provide high returns on the product or brand of environmentally sound, so this variable is thought to affect the quality, safety and value of environmentally friendly products (Bhat \& Reddy, 1998).

Review of the literature indicates that in addition to a positive influence on ecological knowledge, attitudes towards environmentally friendly products are also thought to relate positively with functional attributes. This opinion refers to the study by Hartmann et al. (2005), the hypothesis is formulated:

$\mathrm{H} 2$ : The higher the functional attributes, the higher the positive attitude of environmentally friendly products.

\subsection{Emotional Benefits}

In addition to functional attributes, literature review also indicated a positive relationship between emotional benefits and attitudes towards environmentally friendly products (Hartmann et al., 2005). Emotional benefits associated with environmentally friendly products are concerned about environmental factors, among others: climate protection, assisting with the production, use of the product, removal of competing products conventionally. It can be concluded that the environmentally friendly products that has become life style can motivate consumers to intend to purchase toward these product (Hartmann et al., 2005).

In this study the phenomenon described is the higher the emotional benefits of the product the higher the attitude towards environmentally friendly products. Thus, the hypothesis is formulated:

H3: The higher the emotional benefits, the higher the positive attitude of environmentally friendly products.

\subsection{Attitudes and Behavior Intention toward Environmentally Friendly Products}

In addition to attitudes towards environmentally friendly products, behavioral intention is a variable that is designed as the most relevant predictor variables to determine the behavior. In this study, the intention of purchasing environmentally friendly products is the expression of desire or intention of an individual to commit to activities that support environmental friendliness (Siminin \& Ruth, 1998; Chan, 1999; Pullig \& Biswas, 2006). It also refers to the study Kalafatis et al. (1999) that the intention of purchase of environmentally friendly products is significantly affected by behavioral attitudes, subjective norms, and behavioral control.

Furthermore, the relationship between attitudes and purchase intentions bring environmentally friendly products consumers desire to make the selection of products and in turn consumers are willing to pay for the product at a premium price (Sethuraman \& Cole, 1999). Phenomenon who wants to be explained is the higher the positive attitude towards environmentally friendly products the higher the purchase intent of these products (Sheppart et al., 1998; Simonin \& Ruth, 1998). Thus the hypothesis is formulated: 
H4: The higher the positive attitude towards environmentally friendly products, the higher the intention of purchasing the product.

\section{Method}

\subsection{Sampling Prosedures}

The target population is the potential consumers who intend to purchase a non-CFC air conditioning. Samples were taken with a convenience technique of 200 potential customers who live in Surakarta (Sekaran, 2000). Data was collected through a survey of respondents, through direct interviews were guided by a questionnaire. This is done to increase the seriousness of the answer, and in turn can be expected to obtain research data accuracy.

\subsection{Measurement}

Ecological knowledge is defined as the ability of individuals to identify and define symbols and concepts related to environmental issues (Laroche et al., 2001; Narasimhan, 2003). This variable is operationalized as the degree of consumer knowledge about global warming, air pollution, the benefits of green products, healthful products, eco-friendly products, and radiation.

Functional attribute is defined as the individual's perception of a product in terms of its function. These variables are conceptualized as follows the comfortable, the high quality, the safety, the fun, the high class, the prestige, the high tech, and the exclusive.

Emotional benefits defined as the individual's perception of product quality in terms of the emotions that lead to environmental issues. These variables are conceptualized as follows the friendly, the family, the pollution, and the nature.

Positive attitude towards environment-friendly products is the subjective evaluation of the individual against an environmentally friendly product (Laroche et al., 2001; Narasimhan, 2003; Maciag \& Hepting, 2007). Further attitudes towards green products is measured by the pleasure, the sense of excitement, the positive evaluation, the joy, the happiness, and the positive attitude (Chan, 2001; Laroche et al., 2001).

Purchase intention is defined as the degree of the tendency of individuals to buy products in the long term. This variable is measured by the likely to buy, the expected to buy, the certainty to buy, the tendency to buy, the intention to buy, and the buying preferences in the future (Tellis, 1998; Chan \& Lau, 2000; Chan, 2001).

All items were measured using five-point Likert scale $(1=$ strongly disagree to $5=$ strongly agree $)$.

\subsection{Statistical Analysis}

In this study, hypothesis testing used Structural Equation Model Analysis (SEM Analysis) which is aimed to estimate the simultaneous relationship among of observed variables. Some of the advantages of SEM are (1) the capability in estimating multiple dependent relationships are inter-related, (2) the ability to create concepts that are not observed in the relationship as well as in determining the measurement error in the estimation process, and (3) the ability to accommodate a set of relationships between variables independent and the dependent variable as well as latent variables (Hair et al., 1998).

\section{Results}

\subsection{The Validity and Reliability Test}

The results of the analysis begin by testing the validity and reliability of research instruments. It is intended to ensure the quality of research data to be analyzed with statistical methods chosen. Validity test is done by using Confirmatory Factor Analysis (CFA), and it is expected that each item has loading factor $\geq 0.40$ (Hair et al., 1998). This assumption must be met, because it is one of the requirements to be able to analyze the model with Structural Equation Modeling (SEM). Table 2 indicates that all variables have convergent validity $>0.40$.

Table 2 . Validity test results

\begin{tabular}{llllll}
\hline & Components & & & & \\
\cline { 2 - 6 } Items & 1 & 2 & 3 & 4 & 5 \\
\hline Kn1 & - & .941 & - & - & - \\
Kn2 & - & .802 & - & - & - \\
Kn3 & - & .899 & - & - & - \\
Kn4 & - & .580 & - & - & - \\
Kn5 & - & .733 & - & - & - \\
Kn6 & - & .813 & - & - & - \\
\hline
\end{tabular}




\begin{tabular}{llllll}
\hline At1 & - & - & .794 & - & - \\
At2 & - & - & .602 & - & - \\
At3 & - & - & .857 & - & - \\
At4 & - & - & .705 & - & - \\
At5 & - & - & .639 & - & - \\
At6 & - & - & .765 & - & - \\
Fc1 & .564 & - & - & - & - \\
Fc2 & .523 & - & - & - & - \\
Fc3 & .808 & - & - & - & - \\
Fc4 & .818 & - & - & - & - \\
Fc5 & .900 & - & - & - & - \\
Fc6 & .672 & - & - & - & - \\
Fc7 & .909 & - & - & - & - \\
Fc8 & .656 & - & - & - & - \\
Em1 & - & - & - & - & .756 \\
Em2 & - & - & - & - & .788 \\
Em3 & - & - & - & - & .706 \\
Em4 & - & - & - & - & .837 \\
$\mathrm{Nb} 1$ & - & - & - & .539 & - \\
$\mathrm{Nb2}$ & - & - & - & .867 & - \\
$\mathrm{Nb3}$ & - & - & - & .796 & - \\
$\mathrm{Nb} 4$ & - & - & - & .785 & - \\
$\mathrm{Nb5} 5$ & - & - & - & .560 & - \\
$\mathrm{Nb6}$ & - & - & - & & - \\
\hline
\end{tabular}

In addition to validity, the next is a discussion on the results of reliability testing is performed using Cronbach's Alpha (see Table 3). The test results indicate that all the observed variables are reliable because $>0.70$ (Hair et al., 1998). In summary, based on the results of validity and reliability tests can be summarized that the data deserves to be analyzed with the use of whatever the statistical method chosen.

Table 3. Reliability test results

\begin{tabular}{lll}
\hline Variable & Number of items & Cronbach's Alpha \\
\hline Ecological knowledge & 6 & .797 \\
Attitude & 6 & .807 \\
Functional attributes & 8 & .846 \\
Emotional benefits & 4 & .768 \\
Intention to buy & 6 & .824 \\
\hline
\end{tabular}

\subsection{The Normality Test}

The statistic value which is used to test the normality of the data is the $\mathrm{z}$ value (Critical ratio at the output or CR of AMOS version 4.01). The results of test show the value of skewness and kurtosis of the data distribution. If the $\mathrm{CR}$ value is greater than the critical value, it can be concluded that the data distribution is not normal.

Table 4. Normality test results

\begin{tabular}{|c|c|c|c|c|c|c|}
\hline & Mean & Max & Skewness & $\mathrm{CR}$ & Kurtosis & CR \\
\hline NB6 & 2.000 & 5.000 & -0.126 & -0.726 & -0.625 & -1.804 \\
\hline NB5 & 2.000 & 5.000 & -0.246 & -1.420 & 0.031 & 0.088 \\
\hline NB4 & 2.000 & 5.000 & -0.301 & -1.737 & 0.304 & 0.879 \\
\hline NB3 & 2.000 & 5.000 & -0.255 & -1.475 & 0.201 & 0.582 \\
\hline NB2 & 2.000 & 5.000 & -0.268 & -1.547 & 0.452 & 1.303 \\
\hline NB1 & 2.000 & 5.000 & -0.386 & -2.227 & 0.123 & 0.354 \\
\hline AT6 & 2.000 & 5.000 & -0.282 & -1.626 & 0.723 & 2.087 \\
\hline AT5 & 2.000 & 5.000 & -0.379 & -2.190 & -0.141 & -0.406 \\
\hline AT4 & 2.000 & 5.000 & -0.311 & -1.797 & -0.391 & -1.129 \\
\hline AT3 & 2.000 & 5.000 & -0.231 & -1.335 & -0.007 & -0.021 \\
\hline AT2 & 2.000 & 5.000 & -0.325 & -1.875 & 0.054 & 0.156 \\
\hline
\end{tabular}




\begin{tabular}{|c|c|c|c|c|c|c|}
\hline AT1 & 2.000 & 5.000 & -0.273 & -1.575 & 0.110 & 0.318 \\
\hline EM1 & 2.000 & 5.000 & -0.312 & -1.802 & 0.364 & 1.050 \\
\hline EM2 & 2.000 & 5.000 & -0.095 & -0.548 & -0.378 & -1.091 \\
\hline EM3 & 3.000 & 5.000 & 0.024 & 0.136 & -0.498 & -1.437 \\
\hline EM4 & 2.000 & 5.000 & -0.253 & -1.459 & -0.233 & -0.672 \\
\hline FC8 & 2.000 & 5.000 & -0.206 & -1.189 & -0.378 & -1.090 \\
\hline FC7 & 2.000 & 5.000 & -0.249 & -1.438 & -0.476 & -1.374 \\
\hline FC6 & 2.000 & 5.000 & -0.142 & -0.822 & -0.375 & -1.083 \\
\hline FC5 & 2.000 & 5.000 & -0.300 & -1.729 & -0.125 & -0.361 \\
\hline $\mathrm{FC} 4$ & 2.000 & 5.000 & -0.044 & -0.252 & -0.583 & -1.682 \\
\hline FC3 & 2.000 & 5.000 & -0.293 & -1.693 & 0.135 & 0.391 \\
\hline $\mathrm{FC} 2$ & 2.000 & 5.000 & -0.329 & -1.902 & -0.118 & -0.341 \\
\hline $\mathrm{FC} 1$ & 2.000 & 5.000 & -0.135 & -0.778 & -0.327 & -0.944 \\
\hline KN6 & 2.000 & 5.000 & -0.173 & -0.999 & 0.473 & 1.367 \\
\hline KN5 & 2.000 & 5.000 & -0.294 & -1.700 & -0.049 & -0.141 \\
\hline KN4 & 3.000 & 5.000 & -0.334 & -1.930 & -0.672 & -1.941 \\
\hline KN3 & 2.000 & 5.000 & -0.345 & -1.993 & 0.203 & 0.586 \\
\hline $\mathrm{KN} 2$ & 2.000 & 5.000 & -0.204 & -1.177 & 0.248 & 0.717 \\
\hline \multirow[t]{2}{*}{ KN1 } & 3.000 & 5.000 & -0.011 & -0.063 & -0.143 & -0.412 \\
\hline & & Multivariate & \multicolumn{2}{|c|}{35.050} & \multicolumn{2}{|r|}{5.656} \\
\hline
\end{tabular}

The test results indicate that the value of skewness almost all constructs have values CR under 2, exception items NB1 questions and AT5, while the kurtosis of all constructs have values below 7, which means that the univariate distribution of the data can be considered normal, so it can be used to estimate the subsequent analysis (see Table 4).

$\mathrm{CR}$ value indicates that the data in this study are multivariate normally distributed with kurtosis value of 5.656 CR. Analysis of the data can lead to abnormal refraction interpretation because the value of chi-square analysis results so that the higher the level the smaller the probability value. However, according to Hair et al. (1998:71) a large sample size tends to reduce the adverse effects (distortion analysis results) from the non-normality of the data being analyzed. In addition, Maximum Likelihood Estimation (MLE) techniques used in this study was less affected to the data that is not normal.

\subsection{The Data Outlier}

Data outlier is the next test in order to make as certain that the data is deserves to analysis with SEM. Outlier means the value that comes with extreme values that have different characteristics from other observations and appear in the form of extreme value both for single variables and variable combinations. In a multivariate analysis of outliers was tested by chi-square statistic (X2) to the value of Mahalanobis distance square. This study used a 0.01 significance level variable number of degrees of freedom.

In this case, the variable in question is the number of measurement items on the model. In this study the number of variables that are used by 30 indicator variables. Thus, if there is a value of Mahalanobis distance greater than $\mathrm{X} 2(30 ; 0.001)=59.70221$, then those values are multivariate outliers. Table 5 indicates there are no observations that exceed the value of 59.70221, so it can be concluded that there are no outliers in the data analyzed.

Table 5. Multivariate outlier

\begin{tabular}{llll}
\hline Observation & Mahalanobis & & \\
\hline number & d-squared & $\mathrm{p} 1$ & $\mathrm{p} 2$ \\
\hline 93 & 47.281 & .023 & .003 \\
141 & 46.299 & .029 & .006 \\
8 & 45.388 & .036 & .013 \\
3 & 44.412 & .044 & .031 \\
166 & 44.215 & .046 & .022 \\
143 & 42.708 & .062 & .119 \\
\hline
\end{tabular}

\subsection{The Hypothesis Testing}

Evaluation of the model fit can be seen in table 6. Test results indicate that the model has a relatively good fit, so it can therefore be used as a prediction model that can be accounted for righteousness in statistical side. 
Furthermore, the relation between variables in the hypothesis is shown by the estimate value or standardized regression weights. Based on the SEM output, degree of freedom used is 398. Hypothesis testing is done by analyzing the significance level of causality relationship between the constructs in the model based on the value of CR (z-test) greater than or equal to the value of z-table (z-test>z-table). For the numbers of respondents were more than 12 then the $z$-values tables for each level of significance are: $1 \%=2.56 ; 5 \%=1.96,10 \%=1.645$. The following is an explanation of the results of hypothesis testing.

Table 6. Results of structural equation model

\begin{tabular}{lllll}
\hline Descriptions & Estimate & SE & CR & P \\
\hline Ecological knowledge $\rightarrow$ Attitude & .302 & .111 & 2.730 & $* * *$ \\
Functional attributes $\rightarrow$ Attitude & .246 & .111 & 2.213 & $* * *$ \\
Emotional benefits $\rightarrow$ Attitude & .220 & .103 & 2.136 & $* * *$ \\
Attitude $\rightarrow$ intention to buy & .278 & .112 & 2.477 & $* * *$ \\
\hline $\mathrm{X}^{2}=445.024$ & & & \\
Sig $=.00$ & & & \\
CMIN/DF $=1.118$ & & & \\
GFI $=.877$ & & & \\
AGFI $=.856$ & & & \\
CFI $=.977$ & & & \\
RMSEA $=.024$ & & & \\
RMR $=.024$ & & & \\
TLI $=.975$ & & & \\
NFI $=.819$ & & & \\
\hline
\end{tabular}

4.4.1 The Relation between Ecological Knowledge and Positive Attitude toward Environmentally Friendly Products

The test result of the relationship between ecological knowledge and positive attitudes towards environmentally friendly products indicates that hypothesis 1 supported $(\beta=.302 ; \mathrm{SE}=.111 ; \mathrm{CR}=2.730 ; \mathrm{p}=.01)$. It can be concluded that the ecological knowledge has a positive effect on attitudes toward environmentally friendly products. This can happen because the respondents knew that global warming issues that impact on positive attitudes towards environmental issues which in turn is followed by positive action towards the protection of the environment. Consumers adapt to this situation by considering environmental issues when shopping. Evidence supporting this ecological environment improvement is the willingness of individuals to pay higher prices on products that are environmentally friendly than conventional products.

\subsubsection{The Relation between Functional Attribute and Positive Attitude toward Environmentally Friendly Product}

The test result of the relationship between functional attributes and a positive attitude towards environmentally friendly products indicates that hypothesis 2 supported $(\beta=.246 ; \mathrm{SE}=.111 ; \mathrm{CR}=2.213 ; \mathrm{p}=.01)$. This indicates that the higher the functional attributes inherent in the product the higher the intention to buy the product. This finding is consistent with research conducted by Hartmann et al. (2005) who explains that the functional attributes attached to the product have an impact on cognitive perception that high.

\subsubsection{The Relation between Emotional Benefits and Positive Attitude toward Environmentally Friendly Product}

Further examination of relationships between emotional benefits and a positive attitude towards environmentally friendly products shows the result that support the hypothesis 3 that explains the higher the emotional benefits the higher the positive attitude of environmentally friendly products $(\beta=.220 ; \mathrm{SE}=.103 ; \mathrm{CR}=2.136 ; \mathrm{p}=.01)$. This is consistent with study conducted by Hartmann et al. (2005) who have shown that the emotional benefits of having a significant effect on the brand's positioning relative to the emotional dimension of green brand associations. 
4.4.4 The Relationship between Positive Attitudes towards Environmentally Friendly Products and Purchase Intentions on the Product

Last is testing the relationship between positive attitudes towards environmentally friendly products and purchase intentions on the product indicates that the results support the hypothesis 4 , which explains the higher the positive attitude towards environmentally friendly products, the higher the purchase intention on the product $(\beta=0.278 ; \mathrm{SE}=0.112 ; \mathrm{CR}=2.477 ; \mathrm{p}=.01)$. These findings are consistent with studies conducted by Kalafatis et al (1999) and Chan (1999) who explains that the improved quality of life can be controlled by individuals or consumers by making changes to select and use certain products that are environmentally friendly.

\subsection{Conclusion and Implications}

This study can be concluded that the intention to buy environmentally friendly products can be enhanced through the development of positive attitudes toward the product. Whereas the positive attitude towards environmentally friendly products can be improved through designing stimuli that can build ecological knowledge, it is also the perception of the functional attributes and functional attributes of these products. It is based on the results of empirical testing, which explains that the potential consumers in deciding the purchase of environmentally friendly products not only consider environmental issues, but also consider aspects of the product benefits both functional and emotional that can enhance a sense of pride for its owner.

Furthermore, following is the implications of the study. First, this study expected to be a reference in studies in the field of behavioral consumers. This is caused that the concepts are designed tested through a rigid testing procedures so that the truth can be justified scientifically. Second, this study is also expected to provide an understanding of the practitioner's efforts to market environmentally friendly products through the development of ecological knowledge, designing the product attributes that are functional and rational. Through these efforts are expected to increase the purchase intention of these products. Third, this study relies on research methods are limited in scope, that is the product of non-CFC refrigerator. This condition needs further studies to test the concepts being modeled so that generalizations can be improved.

\section{References}

Aaker, D., \& Shansby, J. (1982). Positioning your Product. Business Horizon, 25(3), 56-62. http://dx.doi.org/10.1016/0007-6813(82)90130-6

Ajzen, I., \& Fishbein M. (1980). Understanding Attitudes and Predicting Social Behavior. Englewood Cliff, New York: Prentice-Hall.

Bhat, S., \& Reddy, S. K. (1998). Symbolic and functional positioning of brands. Journal of Consumer Marketing, 15(1), 32-43. http://dx.doi.org/10.1108/07363769810202664

Blankson, C., \& Kalafatis, S. P. (1999). Issues and challenges in the positioning of service brands: a review. Journal of Product \& Brand Management, 8(2), 106-18. http://dx.doi.org/10.1108/10610429910266968

Chan, R. Y. K. (1999). Environmental attitudes and behavior of consumers in China: Survey findings and implications. Journal of International Consumer Marketing, 11(4), 25-52. http://dx.doi.org/10.1300/J046v11n04_03

Chan, R. Y. K. (2001). Determinants of Chinese consumers green purchase behavior. Psychology and Marketing, 11(4), 389-413. http://dx.doi.org/10.1002/mar.1013

D'Souza, C. (2005). Green Advertising Effects on Attitude and Choice of Advertising Themes. Asia Pacific Journal of Marketing and Logistics, 17(3), 234-256.

Fishbein, M., \& Middlestadt, S. (1995). Noncognitive effects on attitude formation and change: fact or artifact? Journal of Consumer Psychology, 4(2), 181-202. http://dx.doi.org/10.1207/s15327663jcp0402_05

Franzen, G., \& Bouwman, M. (2001). The Mental World of Brands, World Avertising. Research Center, Oxford.

Hair, J. F. Jr., Anderson, R. E., Tatham, R. L., \& Black, W. C. (1998). Multivariate Data Analysis: With Readings (4th ed.). Upper Saddle River, New Jersey: Prentice Hall International, Inc.

Hartmann, P., Ibanez, V. A., \& Sainz, F. J. F. (2005). Green Branding Effects on attitude: functional versus emotional positioning strategies. Departamento de Economý'a de la Empresa y Financiacio'n, Universidad del Paý's Vasco, Bilbao, Spain. Journal Marketing Intelligence \& Planning, 23(1), 9-29. http://dx.doi.org/10.1108/02634500510577447

Holbrook, M. B., \& Moore, W. L. (1981). Feature interactions in consumer judgements of verbal versus pictorial presentations. Journal of Consumer Research, 8, 103-13. http://dx.doi.org/10.1086/208846 
Kalafatis, S. P., Pollard, M., East, R., \& Tsogas, M. H. (1999). Green marketing and Ajzen's theory of planned behavior: a cross-market examination. Journal of Consumer Marketing, 16(5), 441-60. http://dx.doi.org/10.1108/07363769910289550

Kalafatis, S. P., Tsogas, M. H. \& Blankson, C. (2000). Positioning strategies in business markets. Journal of Business \& Industrial Marketing, 15(6), 416-37. http://dx.doi.org/10.1108/08858620010349501

Kotler, P. (2000). Marketing Management (Millennium ed.). Upper Saddle River, NJ: Prentice-Hall.

Laroche, M., Bergeron, J., \& Barbaro, G. (2001). Targeting Consumers Who are Willing to Pay More for Environmentally Friendly Products. Journal of Consumer Marketing, 18(6), 503-520. http://dx.doi.org/10.1108/EUM0000000006155

Maciag, T., \& Hepting, D. (2008). Discovery of Usability Patterns in Support of Green Purchasing. University of Regina, Department of Computer Science, Regina, Saskatchewan, Canada.

Mitchell, A. A., \& Olson, J. C. (1981). Are product attribute beliefs the only mediator of advertising effects on brand attitude? Journal of Marketing Research, 18, 318-32. http://dx.doi.org/10.2307/3150973

Narasimhan, Y. (2003). The Link between Green Purchasing Decisions and Measures of Environmental Consciousness.

Pullig, C., Netemeyer, R. G., \& Biswas, A. (2006). Attitude basis, certainty, and challenge alignment: a case of negative brand publicity. Academy of Marketing Science Journal, 34(4), 528-535. http://dx.doi.org/10.1177/0092070306287128

Schlegelmilgh, B. B., Bohlen, G. M., \& Diamantiopoulus, A. (1996). The link between green purchasing decision and measure of environmental conciousness. European Journal of Marketing, 30(5), 550-562.

Schwartz, S. H. (1994). Are there universal aspects in the structure and contents of human value? Journal of Social Issue, 50, 19-45.

Sekaran, U. (2000). Research Methods For Business: A Skill Building Approach (3rd ed.). New York: John Willey \& Sons, Inc.

Sethuraman, R., \& Cole, C. (1999). Factors influencing the price premium that consumers pay for national brands over store brands. The Journal of Product and Brand Management, 8, 340-351. http://dx.doi.org/10.1108/10610429910284319

Sheppard, B. H., Hartwick, J., \& Warshaw, P. R. (1988). The theory of reasoned action: a meta-analysis of past research with recommendations for modifications and future research. Journal of Consumer Research, 15, 325-343. http://dx.doi.org/10.1086/209170

Simonin, B. L., \& Ruth, J. A. (1998). Is company known by the company it keeps? Assesing the spillover effects of brand alliance on consumer brand attitudes. Journal of Marketing Research, 16, 30-42. http://dx.doi.org/10.2307/3151928

Starughan, R. D., \& Roberts, J. A. (1999). Environmental segmentation alternatives: a look at green consumers behavior in the new millennium. Journal of Consumer Marketing, 16, 558-575. http://dx.doi.org/10.1108/07363769910297506

Tellis, G. J. (1998). Advertising exposure, loyalty, and brand purchase: a two-stage model of choice. Journal of Consumer Marketing, 30, 134-144.

Treager, A., Dent, J. B., \& McGregor, M. J. (1994). The demand for organically grown produce. British Food Journal, 96(1), 79-88.

Vlosky, R. P., Ozanne, L. K., \& Fontenot, R. J. (1999). A conceptual model of US consumer willingness-to-pay for environmentally certified wood products. Journal of Consumer Marketing, 16(2), 122-136. http://dx.doi.org/10.1108/07363769910260498

\section{Copyrights}

Copyright for this article is retained by the author(s), with first publication rights granted to the journal.

This is an open-access article distributed under the terms and conditions of the Creative Commons Attribution license (http://creativecommons.org/licenses/by/3.0/) 